\title{
BOM, BONITO E BARATO...
}

Um paciente o procura e lhe pergunta o que você acha de uma droga nova que acaba de ser lançada no mercado e que foi objeto de uma detalhada e otimista reportagem em uma revista de grande circulação nacional. Você explica ao paciente que de fato esta nova droga é cerca de 10\% mais eficaz do que a que até então era o padrão para aquela doença, mas seu custo é cerca de 10 vezes maior. $\bigcirc$ paciente então lhe pergunta: "Se fosse o senhor, tomaria a droga nova?"

Apesar de representar apenas 18\% do faturamento das companhias farmacêuticas', os custos envolvidos no desenvolvimento de uma nova medicação são muito altos. De fato, o melhor tipo de evidência necessária para a aprovação da maior parte das novas drogas - estudos de fase III controlados - é também muito caro ${ }^{2}$. Desta forma, a introdução de novas drogas tem quase sempre representado um aumento do custo do tratamento de várias doenças ${ }^{3,4}$, o que pode, ao longo dos próximos anos, seriamente ameaçar a higidez financeira de fontes pagadoras privadas e públicas.

Frente a este cenário, como podemos reagir para tentar receitar a nossos pacientes os tratamentos mais eficazes e modernos a um custo absorvível por estas fontes pagadoras? A diminuição do custo de novas medicações, como ocorreu há poucos anos com alguns remédios anti-retrovirais em nosso meio, e o uso de medicações genéricas ${ }^{5}$ podem diminuir substancialmente o custo do tratamento medicamentoso.

Entretanto, só poderemos progredir mais ainda nesta área de diminuição de custos associados à introdução de novas medicações se, em paralelo às linhas de pesquisa das quais derivam estes novos fármacos, associarmos pesquisa que vise especificamente a redução de custos resultantes de sua introdução no mercado. Estas linhas de pesquisa voltadas para a redução de custos não devem ser vistas como antagônicas à consecussão de maiores lucros por empresas farmacêuticas a curto prazo, mas sim como meios de permitir que a sociedade, por meio de fontes pagadoras públicas e privadas, Ihes possa pagar ao longo dos anos pelas novas drogas que estão sendo lançadas e por aquelas que estão ainda em desenvolvimento. Desta forma, este tipo de pesquisa deveria também ser fomentado pela indústria farmacêutica e por agências de pesquisa estatais. Exemplos deste tipo de pesquisa incluem, por exemplo: I) reduzir a dose de medicações sem a perda da sua eficácia. Em nosso meio, por exemplo, demonstramos que a redução da dose preconizada da medicação antiemética granisetron pode produzir igual eficácia à reportada com a dose mais elevada. Tal redução acarretará uma economia estimada em nosso serviço da ordem de $\mathrm{R} \$ 250.000,00$ ao ano ${ }^{6}$; 2) utilização de drogas já presentes no mercado há anos em esquemas de administração diferentes para aumentar ou manter sua eficácia e diminuir a sua toxicidade. Para exemplificar este ponto, há dados na literatura demonstrando que a utilização da anfotericina deoxicolato em infusão endovenosa contínua diminui substancialmente a sua nefrotoxicidade e praticamente abole os sintomas indesejáveis associados à sua infusão mais curta como febre e calafrios ${ }^{7}$. Em nosso meio, tivemos a oportunidade de reproduzir estes resultados (Uehara,R. comunicação pessoal) que são muito similares aos obtidos com as mais novas formulações lipossomais de anfotericina cerca de 300 vezes mais caras do que a anfotericina deoxicolato; e 3) avaliação de quais pacientes podem se beneficiar mais com uma nova droga por meio de estudos farmacogenéticos, de tal sorte a poder selecionar subgrupos restritos de pacientes para os quais uma droga nova e mais cara possa, pela sua maior eficácia, ser plenamente justificada. Tal situação ocorre, por exemplo, ao identificarmos pacientes com carcinoma pulmonar cujo receptor para o fator de crescimento epitelial (EGFR) albergue mutações específicas que, por sua vez, aumentam a eficácia do tratamento com a droga recentemente aprovada para bloquear este receptor, o Gefinitib $^{8,9}$. Se escolhermos apenas os cerca de $8 \%$ a 20\% de pacientes com esta mutação para administrarmos esta droga, economizaremos substancialemente por não a aplicarmos aos 85\% remanescentes para os quais esta droga teria grandes chances de não funcionar.

Concluímos que se quisermos dizer: "sim, usaria a nova droga em seu caso" para o paciente acima descrito aumentaremos inevitavelmente o custo de nosso tratamento e, para que as fontes pagadoras possam continuar contemplando nossas escolhas terapêuticas, deveremos desenvolver pesquisas que visem diminuir o custo resultante da introdução destas novas drogas. Este tipo de pesquisa deve ser fomentado com a mesma intensidade e prioridade como é a pesquisa envolvida no desenvolvimento de novos fármacos. Só assim o bom e bonito se tornará barato.

Auro del Giglio

\section{Referências}

I. Scherer FM. The pharmaceutical industry — prices and progress. N EngI] Med 2004:35I(9):927-32.

2. Zivin JA. Understanding clinical trials. Sci Am 2000;282(4):69-75.

3. Schrag D. The price tag on progress - chemotherapy for colorectal cancer. $N$ Engl J Med 2004;35I (4):3 I 7-9.

4. Bodenheimer T. High and rising health care costs. Part 2: technologic innovation.Ann Intern Med 2005: | 42 ( | | ):932-7.

5. Haas JS, Phillips KA, Gerstenberger EP, Seger AC. Potential savings from substituting generic drugs for brand-name drugs: medical expenditure panel survey, 1997-2000. Ann Intern Med 2005; I42(I I):89|-7. Summary for patients in: Ann Intern Med. 2005 Jun 7; | 42 ( I I):130.

6. Moreno J, Sahade M, Del Giglio A. Low-dose granisetron for prophylaxis of acute chemotherapy-induced nausea and vomiting: a pilot study. Support Care Cancer 2005. Avaliable from: http://www.ncbi.nlm. nih.gov/entrez query.fcgi? $\mathrm{cmd}=$ Retrieve\&db $=$ pubmed\&dopt $=$ Abstract\&list uids $=|58386|$ \&\&query $\mathrm{h}|=| 4$. 7. Eriksson U, Seifert B, Schaffner A. Comparison of effects of amphotericin B deoxycholate infused over 4 or 24 hours: randomised controlled trial. BMJ 2001;322(7286):579-82.

8. Lynch TJ, Bell DW, Sordella R, Gurubhagavatula S, Okimoto RA, Brannigan BW, Harris PL, Haserlat SM, Supko JG, Haluska FG, Louis DN, Christiani DC, Settleman J, Haber DA. Activating mutations in the epidermal growth factor receptor underlying responsiveness of non-small-cell lung cancer to gefitinib. $N$ Engl J Med 2004;350(21):2129-39.

9. Shigematsu H, Lin L, Takahashi T, Nomura M, Suzuki M, Wistuba II, et al. Clinical and biological features associated with epidermal growth factor receptor gene mutations in lung cancers. J Natl Cancer Inst 2005;97(5):339-46. 